\title{
Use of molecular techniques for the analysis of the microbiological quality of fish marketed in the municipality of Cuiabá, Mato Grosso, Brazil
}

\author{
Débora Cristina PASTRO ${ }^{1 *}$, Sandra MARIOTTO ${ }^{1}$, Erika Cerqueira SANTOS ${ }^{1}$, Daniela Cristina FERREIRA ${ }^{2}$, \\ Gilma Silva CHITARRA ${ }^{1}$
}

\begin{abstract}
The present study was stimulated by the growing demand for healthy food and the technology available for the detection and identification of microbial organisms in fishery products. Molecular tools were used to identify the bacterial community and detect the presence of pathogenic species in samples of farmed and wild-caught fish. Samples of muscle tissue were obtained from the local market in Cuiabá, Mato Grosso, Brazil. The 16S rDNA gene was used to detect 11 bacterial genera: Enterobacter (29.29\%), Aeromonas (24.24\%), Pseudomonnas (17.17\%), Enterococcus (10.10\%), Acinetobacter (6.06\%), Citrobacter (4.04\%), Bacillus (3.03\%), Klebsiella and Lactococcus (2.02\%), and Clostridium and Lysinibacillus (1.01\%). High percentages of deleterious bacteria were recorded. Species-specific primers were used to detect the presence of Escherichia coli (35.71\%), Staphylococcus aureus (12.5\%), and Salmonella (7.14\%), although Shigella was absent. These concentrations exceeded the limits established by the currently public health legislation. The molecular techniques used in the present study provide an alternative approach for the reliable diagnosis of contamination, which can be used on a large scale.
\end{abstract}

Keywords: Contamination, Aquaculture, Public health.

Practical Application: molecular techniques provide effective detection of bacteria in fishery products.

\section{Introduction}

Brazil is a country with enormous potential for fish farming due to its abundance of water resources and favourable climate. In 2013, the state of Mato Grosso produced 105 thousand tons of fish, and was the principal producer of the Midwest region (Brasil, 2014).

There is an increasing demand for fishery products, driven by the quality of fish meat as a food, in particular its polyunsaturated fatty acids, such as Omega 3 , high protein content, digestibility, and the presence of vitamins, essential amino acids, iron, phosphorus, and calcium. However, these products are also highly vulnerable to contamination by microorganisms and rapid deterioration.

A number of pathogenic bacteria, such as Vibrio, Aeromonas and Clostridium, are present naturally in terrestrial and, in particular, aquatic environments. Contamination by pathogenic bacteria such as Escherichia coli, Salmonella and Shigella often occurs through contact with fecal matter or polluted water. This contamination may occur either prior to or following the harvesting of the fish, while inadequate handling during the preparation of the product may result in the introduction of Staphylococcus aureus (Onyango et al., 2009).

Conventional techniques for the microbiological analysis of fishery products are expensive, time-consuming, and often vulnerable to errors. Molecular techniques provide a rapid and reliable diagnosis, with the potential for the more efficient control of the marketing of fishery products, providing insights into the productive chain and shifts in microbe diversity.

Given the increasing demand for fishery products in the Brazilian state of Mato Grosso, it is essential to develop reliable quality controls. In the present study, molecular techniques were used to detect bacteria and evaluate the microbiological quality of the fish species sold to the public in the municipality of Cuiabá, capital of the state of Mato Grosso, Brazil.

\section{Materials and methods}

\subsection{Experimental design}

Experiment 1. Detection of the bacterial genera present in wild-caught and farmed fish using the $16 \mathrm{~S}$ rDNA gene. This experiment was a descriptive survey for the definition of the microbiological quality of the samples and the identification of the bacterial genera. Each sample of muscle tissue was considered to be an experimental unit, with a total of 66 samples being analyzed.

Experiment 2. Detection of pathogenic bacteria in wild-caught and farmed fish using species-specific primers. This experiment 
also adopted a descriptive approach for the definition of the microbiological quality of the samples and the identification of pathogenic bacterial species and genera. Each sample of muscle tissue was counted as an experimental unit, with a total of 56 samples being analyzed.

\section{Experiment 1: collection of samples}

Samples of muscle tissue were acquired from 66 fish specimens, of which 26 were farmed and 40, wild-caught. The specimens were obtained from supermarkets, fishmongers, and street markets in the municipality of Cuiabá, Mato Grosso state, Brazil. The farmed species were the tambatinga, a Colossoma macropomum (tambaqui) x Piaractus brachypomus (pirapitinga) hybrid, the tambacu, a C. macropomum x Piaractus mesopotamicus (pacu) hybrid, and the catfish Pimelodus maculatus. The specimens were all farmed locally within the Cuiabá region.

The wild-caught species were the spotted surubim (Pseudoplatystoma corruscans), pacu (Piaractus mesopotamicus), matrinxã (Brycon cephalus), piraputanga (Brycon hilarii), and barred surubim (Pseudoplatystoma fasciatum). These species are fished from the Cuiabá and Paraguay rivers in the upper Paraguay basin, and the upper Amazon basin. No specimens were removed from their natural habitat or euthanized specifically for this study.

The fresh or chilled specimens were placed in sterile plastic containers, which were stored in coolers with ice packs for transportation to the Animal Genetics Laboratory on the Cuiabá campus of the Federal University of Mato Grosso (UFMT).

\section{Experiment 1: bacterial culture}

The bacterial culture was based on the procedures defined by APHA (American Public Health Association, 2001) and Silva et al. (2010).

\section{Experiment 1: extraction of the DNA}

The DNA was extracted from the bacterial colonies using an $\mathrm{RTP}^{\circledR}$ Bactéria DNA mini extraction kit (STRATEC Molecular), following the manufacturer's protocol. The quality and integrity of the DNA were evaluated by electrophoresis in $1 \%$ agarose gel at $120 \mathrm{~V}$, using a transilluminator with an attached photographic documenter (Loccus Biotecnology ${ }^{\circledR}$ ). The DNA was quantified in a DeNovix ${ }^{\circledR}$ DS-11 nano-spectrophotometer.

\section{Experiment 1: Polymerase Chain Reaction (PCR)}

The $16 \mathrm{~S}$ ribosomal subunit (16S rDNA) was amplified using forward oligonucleotide primer 968: 5' AAC GCG AAG AAC CTT AC 3' and reverse primer 1401: 5' CGG TGT GTA CAA GAC CC 3' (Sambrook et al., 1989). The Polymerase Chain Reaction (PCR) was run according to the protocol of Motlagh \& Anvari (2010), and the amplified products, of approximately $410 \mathrm{bps}$, were analyzed by gel electrophoresis in $1.5 \%$ agarose gel, run at $120 \mathrm{~V} / \mathrm{cm}$ for 40 minutes. The gel was stained with fluorescent GelRed dye and blue juice (1:1), and visualized in a transilluminator with an attached photographic documenter (Loccus Biotecnology $y^{\circledR}$ ).

The purified PCR products were sent to Myleus Biotechnology ${ }^{\circledR}$ (Myleus Food Safety, 2016) for sequencing, following the company's protocol for the preparation and shipment of samples.

\section{Experiment 1: analysis of the nucleotide sequences}

The sequences obtained from these analyses were visualised in Chromas Lite (v. 2.1.1). The initial and final portions of each sequence were removed to guarantee the quality of the fragments, and the sequences were then exported in FASTA format and compared with bacterial sequences deposited in GenBank (National Center for Biotechnology Information, 2016a; Table 1) using BLAST (National Center for Biotechnology Information, 2016b). These alignments were $72-98 \%$ consistent with the GenBank sequences, and were considered adequate for the identification of the bacterial genera.

\section{Experiment 2: sample collection}

Muscle tissue samples were obtained from 56 fish specimens, of which 19 were farmed and 37, wild-caught. The specimens were obtained from supermarkets, fishmongers, and street markets in Cuiabá. The farmed species were the tambatinga (C. macropomum $\times$ P. brachypomus), tambacu (C. macropomum $\mathrm{x}$ P. mesopotamicus), the catfish Pimelodus maculatus, tetra (Astyanax bimaculatus), and arapaima (Arapaima gigas).

Wild-caught species included the spotted surubim (Pseudoplatystoma corruscans), pacu (Piaractus mesopotamicus), spotted shovel-nose catfish Hemisorubim platyrhynchos), pacupeva (Metynnis maculatus), flatwhiskered catfish (Pinirampus pinirampus), piraputanga (Brycon hilarii), and barred surubim (Pseudoplatystoma fasciatum). The farmed and wild-caught fish were all obtained from the same area as in experiment 1.

\section{Experiment 2: extraction of the DNA}

The DNA was extracted from the samples of muscle tissue using the protocol of APHA (American Public Health Association, 2001) and Silva et al. (2010). No bacterial culture

Table 1. Bacterial genera analyzed in the present study and their GenBank access numbers.

\begin{tabular}{cc}
\hline Bacterial genus & GenBank access number \\
\hline Acinetobacter & KF681154.1 \\
Aeromonas & KR189942.1 \\
Bacillus & KR265687.1 \\
Citrobacter & JN987149.1 \\
Clostridium & JF312732.1 \\
Enterobacter & KM032850.1 \\
Enterococcus & KF000371.1 \\
Klebsiella & JF501149.1 \\
Lactococcus & KM596908.1 \\
Lysinibacillus & KC310819.1 \\
Pseudomonas & KF681154.1 \\
\hline
\end{tabular}


was obtained from the muscle tissue. The bacteria present in the $0.1 \%$ peptone water were enriched in Brain Heart Infusion (BHI) broth for 18 hours at $35^{\circ} \mathrm{C}$, after which the DNA was extracted as in experiment 1.

\section{Experiment 2: Polymerase Chain Reaction (PCR)}

Species-specific primers (Table 2) were used to detect four strains of pathogenic bacteria: Salmonella, E. coli, Shigella, and Staphylococcus aureus. The PCRs were run according to Motlagh \& Anvari (2010), with the appropriate annealing temperature (Tm) being used for each species-specific primer (Primer-BLAST- National Center for Biotechnology Information, 2016b). The PCR products were analyzed as described in experiment 1, with the negative and positive controls being applied. The positive control was based on strains provided by the Nutritional Laboratory at the Federal University of Mato Grosso in Cuiabá, which were acquired from New Prov ${ }^{\circledR}$. The amplified products were visualized in a transilluminator with an attached photographic documenter (Loccus Biotecnology ${ }^{\circledR}$ ). The samples were considered positive when the respective amplicons produced a visible band, with the size of the sequence being measured in base pairs (see Table 2).

\section{Results and discussion}

\subsection{The 16S rDNA gene}

The sequencing of the $16 \mathrm{~S}$ rDNA gene identified the presence of 11 bacterial genera in the fish samples (Figure 1). These same bacteria have been encountered in samples of a number of fish species, including those studied here and others, such as carp and tilapia, analyzed in the Brazilian states of Mato Grosso do Sul, São Paulo, Paraná, and Rio de Janeiro (Sebastião et al., 2015).

The genera Pseudomonnas, Klebsiella, Bacillus, Citrobacter and Enterobacter have been isolated from samples of muscle tissue and other organs of a number of fish species, and in the water of fish-farming ponds (Apun et al., 1999; Yagoub, 2009). These findings indicate that the presence of the bacterial genera identified in the present study may have been derived from the contamination of the aquatic environment, which is propitious to bacterial development.

Enterobacter, a coliform bacterium, was the most frequently recorded (29.29\% of the specimens) in the present study (Figure 1). The species of this genus are widely distributed in humans and animals, and also in standing water, sewers, and soils, and represent a major threat to public health (Rajasekaran, 2012). The presence of this genus is typical of the fecal contamination of foodstuffs (Baylis et al., 2011). Given this, the results of the present study indicate that the fish specimens may have been contaminated in the aquatic environment, as a result of the discharge of untreated sewage into reservoirs and rivers. These bacteria are easily eliminated by heating, although, the consumption of raw or undercooked fish can be problematic, and cross-contamination can also be an important source of infection or food poisoning (Lorenzon et al., 2010).

The inadequate handling of fishery products during transportation, processing, and storage may facilitate the proliferation of the pathogens present in the material (Food and Agriculture Organization, 2015). Some of the bacteria identified in the present study, such as Pseudomonas, Acinetobacter and Bacillus, may have derived from the natural intestinal flora of the fish (Kim et al., 2007), and their presence in the specimens was likely derived from either the inadequate manipulation of the fish during gutting or by washing them with contaminated water.

In the present study, considering only the wild-caught specimens (40 samples), a total of seven bacterial genera were recorded: Aeromonas (32.08\% of the specimens), Enterobacter (22.64\%),

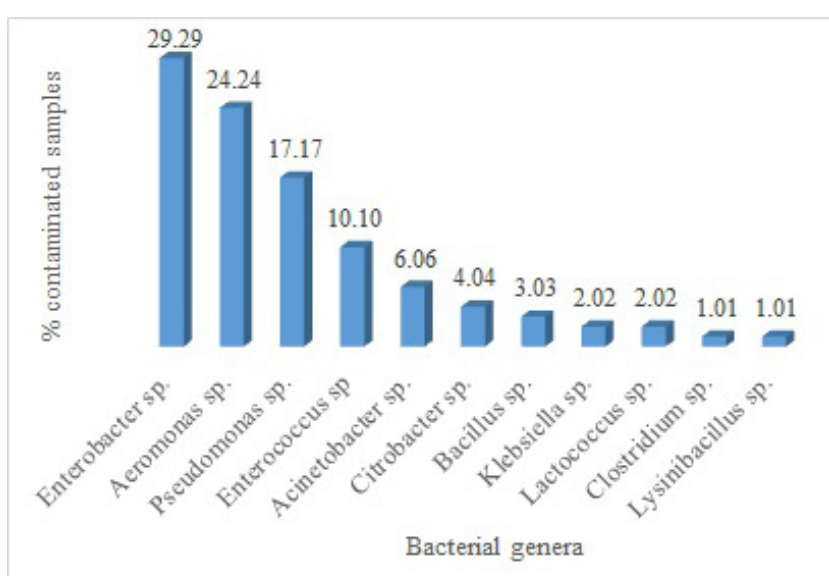

Figure 1. Percentage of bacterial contamination detected in farmed and wild-caught fish species marketed in Cuiabá, Mato Grosso (Brazil) in 2016. The bacteria were identified by sequencing the $16 \mathrm{~S}$ rDNA gene in samples of the muscle tissue of 66 fish specimens.

Table 2. Sequences of the species-specific primers used in the present study, and their respective references.

\begin{tabular}{|c|c|c|c|c|}
\hline Bacterium & Primer sequence & Molecular weight & Gene & Reference \\
\hline Staphylococcus aureus & $\begin{array}{l}\text { F:5’ -ATG AAG TCA AAT AAA TCG CT-3' } \\
\text { R:5’ -TTT GGT GAA AAA TAC TTC TC-3' }\end{array}$ & $458 \mathrm{bps}$ & $\mathrm{nuC}$ & Gandra et al. (2011) \\
\hline Salmonella sp. & $\begin{array}{l}\text { F:5' -TTG GTG TTT ATG GGG TCG TT-3' } \\
\text { R:5' -GGG CAT ACC ATC CAG AGA AA-3' }\end{array}$ & $298 \mathrm{bps}$ & invA & Suh \& Song (2005) \\
\hline Escherichia coli & $\begin{array}{l}\text { F: 5' -GTT GTC GCT GAA GCA ACT GG-3' } \\
\text { R:5'- AGC GTT GGA AAC GAT GTC CT-3' }\end{array}$ & $171 \mathrm{bps}$ & gapA & Blumer et al. (2005) \\
\hline Shigella & $\begin{array}{l}\text { F:5'-GTTCCTTGACCGCCTTTCCGATACCGTC3' } \\
\text { R:5' -GCCGGTCAGCCACCCTCTGAGAGTAC-3' }\end{array}$ & $620 \mathrm{bps}$ & ipaH & Song et al. (2005) \\
\hline
\end{tabular}


Pseudomonas (22.64\%), Enterococcus (9.43\%), Acinetobacter (5.66\%), Citrobacter (3.77\%), and Bacillus (3.77\%), which were recorded in all five species analyzed.

Aeromonas, which in pathogenic in both humans and fish, and is common in aquatic environments, was recorded most frequently in this study. The presence of bacteria is related to the pollution of the water, and cross-contamination through inadequate handling, storage, transportation, and distribution (Kirkan et al., 2005).

In Brazil, Aeromonas has been recorded in both wild-caught and farmed fish, although there is no specific legislation on the identification and quantification of this pathogen in water and foodstuffs. As this pathogen is not contemplated by existing Brazilian legislation, and is thus not routinely investigated, it can be an obstacle to fish farming, resulting in economic losses and potentially serious health risks for consumers (Rall et al., 1998).

Some bacteria, such as Aeromonas and Pseudomonas, are often found in farm pools, and the fish raised in these environments may be contaminated through contact with the environment, ration, birds, domestic animals, and farmworkers (Shama et al., 2000). Enterobacter and Enterococcus are considered to be indicators of fecal contamination. Pseudomonas, Acinetobacter and Citrobacter were also detected in the present study, and are considered to be an important cause of the spoiling of both raw and processed foodstuffs (Baylis et al., 2011; Yagoub, 2009).

Bacillus has been identified in fish and contains pathogenic species that caused food-related gastroenteritis, as well as others that are capable of spoiling foodstuffs. As these bacteria are part of the normal intestinal flora of fish, cross-contamination may occur through inadequate handling (Kim et al., 2007). The bacterial genera recorded in the wild-caught fish indicates that these fishery products are a potential source of pathogenic and/or degenerative bacteria, and require good-quality water and special care during handling, transportation, and storage, to minimize the risks to public health.

Eleven bacterial genera found in the 26 samples of farmed fish (tambatinga, catfish, and tambacu), including Enterobacter (35.55\%), Aeromonas (15.56\%), Pseudomonnas (11.11\%), Enterococcus (11.11\%), Acinetobacter (6.67\%), Citrobacter (4.44\%), Klebsiella (4.44\%), Lactococcus (4.44\%), Clostridium (2.22\%), Lysinibacillus (2.22\%), and Bacillus (2.22\%). A much greater microbial diversity was thus found in the farmed fish, despite the smaller sample analyzed (26 specimens in comparison with 40 wild-caught fish). In the present study, the presence of Klebsiella, Lactococcus, Clostridium and Lysinibacillus was not recorded in the wild-caught fish.

Klebsiella is a coliform that contributes to the spoiling of food. This genus is common in the soil and water, although there are no conclusive data on its role as a pathogen (Tortora et al., 2012). Few data are available on the occurrence of Clostridium in farmed fish, although Clostridium botulinum, which is considered to be pathogenic, has been detected in saltwater fish (Aheroumand, 2010). Lactococcus is classified as an emerging pathogen in fish species, causing disease and provoking economic losses (Vendrell et al., 2006). Few data are available on the contamination of fishery products by Lysinibacillus.
Overall, these findings indicate that the molecular identification of the bacteria present in food using the 16S rRDNA gene is simple, rapid, and efficient, and can be applied on a large scale (Gevers et al., 2006).

\subsection{Species-specific primers}

The food industry requires rapid and reliable methods to monitor the presence of pathogenic bacteria in foodstuffs, especially considering that the available, conventional techniques all depend on intensive, time-consuming laboratory processes, which are relatively ineffective for epidemiological control. Techniques based on DNA sequencing can be used for the detection and identification of pathogenic micro-organisms in foodstuffs.

In this context, the use of species-specific primers provides a rapid method that does not require bacterial culture, and can provide complementary analyses for the standard laboratory routines, and the food industry (Revolledo \& Ferreira, 2009). In the present study, bacteria were detected in the samples of both farmed and wild-caught fish (Figure 2).

In the present study, E. coli was detected in 20 of the 56 samples (35.71\%) analyzed, of which, 16 were obtained from wild-caught fish, and four from farmed animals. Escherichia coli is the principal indicator of the fecal contamination of foodstuffs, and is not part of the natural biota of fish habitats. In this case, the presence of this bacterium in the samples of wild-caught fish probably indicate contamination of the water through the discharge of domestic sewage resulting in the contamination of the fish. The occurrence of pathogenic bacteria in aquatic environments is a major public health problem, and emphasizes the need for the adequate treatment of sewage to minimize the environmental impacts of urbanization (Medeiros et al., 2014). The presence of E.coli may also derive from deficiencies in the productive chain, from harvesting to the final consumer (Onyango et al., 2009; Polimetla \& Kunda, 2013).

The current Brazilian legislation (resolution RDC 12/2001) recommends the absence of Salmonella from a $25 \mathrm{~g}$ sample of fish, fresh or chilled. Salmonella was detected in four samples

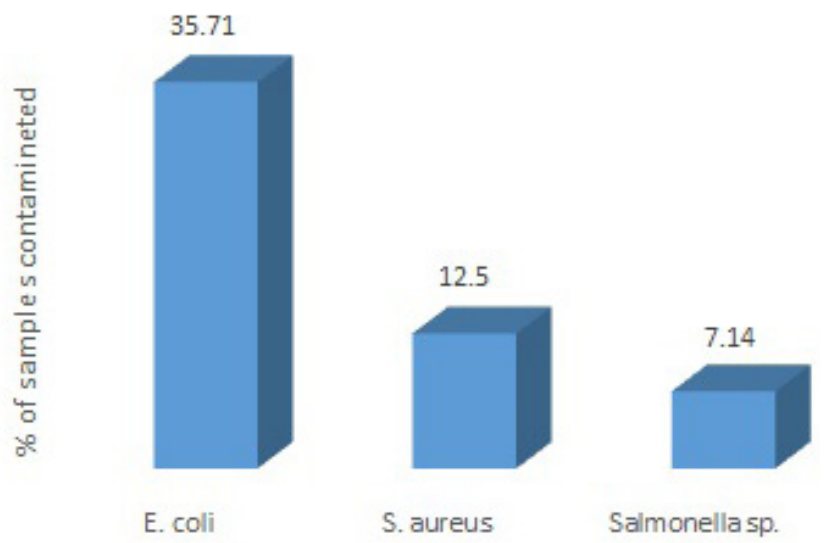

Figure 2. Pathogenic bacteria detected by species-specific primers in samples of muscle tissue from wild-caught and farmed fish marketed in Cuiabá, Mato Grosso, Brazil, in 2016. 
(7.14\%), three of which were obtained from wild-caught fish and one from a farmed fish, all considered to exceed the legal limit (Brasil, 2001). Salmonella is also absent from the natural biota of fish habitats, but is present in the intestinal tract of animals such as birds, and its presence in fishery products derives from inadequate handling or the use of contaminated water (Cardoso \& Carvalho, 2006).

Staphylococcus aureus was recorded in seven fish samples (12.5\%), four wild-caught and three farmed specimens, which indicates contamination from inadequate handling during the productive chain. Staphylococcus aureus is derived from a number of sources, such as the air, fresh- and saltwater, the soil, and plants. In humans, S. aureus can be found in the respiratory tract, nasal mucosa, and skin, and foods can be contaminated when handled by individuals that have inadequate personal hygiene. A number of Staphylococcus species can cause food poisoning, although $S$. aureus is especially problematic because it forms its own toxins (Adams \& Moss, 2008; Lorenzon et al., 2010).

\subsection{All the samples tested negative for Shigella.}

The growing demand for fishery products in the Brazilian state of Mato Grosso means that this resource is increasingly important for the state's economy. While the local diversity of fish species attracts sports fishing enthusiasts and supports a rich local gastronomy, fishery products are highly vulnerable to contamination, and it is fundamentally important to ensure that adequate controls are in place to guarantee the quality of these products.

\section{Conclusions}

The analysis of fishery products using molecular techniques demonstrated that the muscle tissue of wild-caught and farmed fish marketed in Cuiabá contains high concentrations of bacteria that reduce the quality of the product, accelerate spoiling, and increase the risk of infection and food poisoning.

The bacterial taxa were identified using 16S rDNA gene sequences, and the application of species-specific primers provided a rapid and reliable diagnosis. The techniques employed in this study proved to be a highly reliable diagnostic tool that can be applied to the monitoring and analysis of samples on a large scale.

\section{Acknowledgements}

We are grateful to the Mato Grosso State Research Foundation (FAPEMAT) for providing a study stipend, and the Brazilian National Council for Scientific and Technological Development (MEC/SETEC/CNPq) for financing this project.

\section{References}

Adams, M. R., \& Moss, M. O. (2008). Food microbiology (Vol. 3, p. 252-256). Cambridge: Royal Society of Chemistry.

Aheroumand, A. (2010). Occurrence of Clostridium botulinum in fish and fishery products in retail trade, a review article. World Journal of Fish and Marine Sciences, 2(3), 246-250.

American Public Health Association - APHA. (2001). Committee on microbiological methods for foods. Compendium of methods for the microbiological examination of foods (4th ed., p. 676). Washington: American Public Health Association.

Apun, K., Yusof, A. M., \& Jugang, K. (1999). Distribution of bacteria in tropical freshwater fish and ponds. International Journal of Environmental, 9, 285-292.

Baylis, C., Uyttendaele, M., Joosten, H., \& Davies, A. (2011). The enterobacteriaceae and their significance to the food industry (ILSI Europe Report Series, p. 17-28). Brussels: ILSI Europe Publications.

Blumer, C., Kleefeld, A., Lehnen, D., Heintz, M., Dobrindt, U., Nagy, G., Michaelis, K., Emödy, L., Polen, T., Rachel, R., Wendisch, V. F., \& Unden, G. (2005). Regulation of type 1 fimbriae synthesis and biofilm formation by the transcriptional regulator LrhA of Escherichia coli. Microbiology, 151(10), 3287-3298. http://dx.doi.org/10.1099/ mic.0.28098-0. PMid:16207912.

Brasil. Agência Nacional de Vigilância Sanitária. (2001). Aprova o regulamento técnico sobre o' padrões microbiológicos para alimentos (Resolução RDC 12, de 02 de janeiro de 2001). Diário Oficial [da] República Federativa do Brasil. Retrieved from http:// www.anvisa. gov.br/legis/resol/12_01rdc.htm

Brasil. (2014). Portal Brasil. Retrieved from http://www.brasil.gov.br/ economia-e-emprego/2014/12/maiores-produtores-de-peixes-dobrasil-nao-estao-no-litoral-e-sim-no-centro-oeste-mostra-ibge. 2010

Cardoso, T. G., \& Carvalho, V. M. (2006). Toxifecção alimentar por Salmonella spp. Revista do Instituto de Ciências da Saúde, 24(2), 95-101.

Food and Agriculture Organization - FAO. (2015). Estatísticas. Retrieved from http://www.fao.org/wairdocs/tan/x5902e/x5902e01.htm

Gandra, E. A., Fernandez, M. A., Silva, J. A., \& Silva, W. P. (2011). Standardization of a multiplex PCR for the identification of coagulasepositive Staphylococcus. Food Science and Technology (Campinas), 31(4), 946-949. http://dx.doi.org/10.1590/S0101-20612011000400019.

Gevers, D., Dawyndt, P., Vandamme, P., Willems, A., Vancanneyt, M., Swings, J., \& De Vos, P. (2006). Stepping stones towards a new prokaryotic taxonomy. Philosophical Transactions of the Royal Society of London. Series B, Biological Sciences, 361(1475), 1911-1916. http:// dx.doi.org/10.1098/rstb.2006.1915. PMid:17062410.

Kim, D. H., Brunt, J., \& Austin, B. (2007). Microbial diversity of intestinal contents and mucus in rainbow trout (Oncorhynchus mykiss). Journal of Applied Microbiology, 102(6), 1654-1664. http://dx.doi. org/10.1111/j.1365-2672.2006.03185.x. PMid:17578431.

Kirkan, S., Goksoy, E. O., \& Kaya, O. (2005). Identification and antimicrobial susceptibility of Staphylococcus aureus and coagulase negative from bovine mastitis in the Aydin region of Turkey. Veterinary Animal Science, 29, 791-796.

Lorenzon, C. S., Gatti, J. P., Nunes, A. P., Pinto, F. R. C., Scholten, S. N., \& Honda, L. A. (2010). Perfil microbiológico de peixes e água de cultivo em pesque-pagues situados na região nordeste do Estado de São Paulo. Arquivos do Instituto Biológico, 77(4), 617-624.

Medeiros, J. D., Araújo, L. X., Silva, V. L., Diniz, C. G., Cesar, D. E., Del'Duca, A., \& Coelho, C. M. (2014). Characterization of the microbial community in a lotic environment to assess the effect of pollution on nitrifying and potentially pathogenic bacteria. Brazilian Journal of Biology $=$ Revista Brasileira de Biologia, 74(3), 612-622. http://dx.doi.org/10.1590/1519-6984.26712. PMid:25296210.

Motlagh, M. R. S., \& Anvari, M. (2010). Genetic variation in a population of Bipolaris oryzae based on RAPD-PCR in north of Iran. African Journal of Biotechnology, 9, 5800-5804.

Myleus Food Safety. (2016). Retrieved from www.myleus.com

National Center for Biotechnology Information - NCBI. (2016a). GenBank Overview. Retrieved from http://www.ncbi.nlm.nih.gov/genbank/ 
National Center for Biotechnology Information - NCBI. (2016b). Primer-BLAST. Retrieved from http://www.ncbi.nlm.nih.gov/tools/ primer-blast/

Onyango, M. D., Wandili, S., Kakai, R., \& Waindi, E. N. (2009). Isolation of Salmonella and Shigella from fish harvested from the Winam Gulf of Lake Victoria, Kenya. Journal of Infection in Developing Countries, 3(2), 99-104. PMid:19755738.

Polimetla, B., \& Kunda, S. K. (2013). Prevalence of Escherichia coli in food fishes assessed from domestic retail fish market, Guntur city, Andhra Pradesh, India: a case study. International Journal of Engineering Science and Technology, 5(7), 1545-1552.

Rajasekaran, P. (2012). Enterobacteriaceae group of organisms in sewage-fed fishes. Biotechnology Advances, 8, 12-14.

Rall, V. L. M., Iaria, S. T., Heidtmann, S., Pimenta, F. C., Gamba, R. C., \& Pedroso, D. M. M. (1998). Aeromonas species isolated from fish (Pseudoplatystoma sp.), virulence factors and drug susceptibility. Revista de Microbiologia, 29(3), 222-227. http://dx.doi.org/10.1590/ S0001-37141998000300015.

Revolledo, L., \& Ferreira, A. J. P. (2009). Patologia aviária. Barueri: Manole.

Sambrook, J., Edward, F. F., \& Tom, M. (1989). Molecular cloning (Vol. 2, p. 14-19). New York: Cold Spring Harbor Laboratory Press.

Sebastião, F. A., Furlan, L. R., Hashimoto, D. T., \& Pilarski, F. (2015). Identification of bacterial fish pathogens in Brazil by direct colony PCR and 16S rRNA gene sequencing. Advances in Microbiology, 5(06), 409-424. http://dx.doi.org/10.4236/aim.2015.56042.
Shama, S., Brandão, D. A., Vargas, A. C., Costa, M. M., \& Pedrozo, A. F. (2000). Bactérias com potencial patogênico nos rins e lesões externas de jundiás (Rhamdia quelen) cultivados em sistema semiintensivo. Ciência Rural, 30(2), 293-298. http://dx.doi.org/10.1590/ S0103-84782000000200016.

Silva, N., Junqueira, V. C. A., Silveira, N. F. A., Taniwaki, M. H., Santos, R. F. S., \& Gomes, R. A. R. (2010). Manual de métodos de análise microbiológica de alimentos e água. Livraria Varela, 4, 1-50.

Song, T., Toma, C., Nakasone, N., \& Iwanaga, M. (2005). Sensitive and rapid detection of Shigella and enteroinvasive Escherichia coli by a loop-mediated isothermal amplification method. FEMS Microbiology Letters, 243(1), 259-263. http://dx.doi.org/10.1016/j. femsle.2004.12.014. PMid:15668027.

Suh, D. K., \& Song, J. C. (2005). Simultaneous detection of Lawsonia intracellularis, Brachyspira hyodysenteriae and Salmonella spp. in swine intestinal specimens by multiplex polymerase chain reaction. Journal of Veterinary Science, 6(3), 231-237. PMid:16131827.

Tortora, G. J., Funke, B., \& Case, C. L. (2012). Microbiologia. Porto Alegre: Artmed.

Vendrell, D., Balcázar, J. L., Ruiz-Zarzuela, I., Blas, I., Gironés, O., \& Múzquiz, J. L. (2006). Lactococcus garvieae in fish: a review. Comparative Immunology Microbiolgy Infectious Diseases, 29(4), 177-198. https://doi.org/10.1016/j.cimid.2006.06.003.

Yagoub, S. O. (2009). Isolation of Enterobacteriaceae and Pseudomonas spp. from raw fish sold in fish market in Khartoum state. Journal of Bacteriology, 1(7), 85-88. 